\title{
CETOCOEN Project: From the Laboratory to the Field and Beyond
}

\author{
Jana Klánová ${ }^{1}$, Luděk Bláha ${ }^{1}$, Jiří Damborský ${ }^{1,2}$, Petr Klán ${ }^{1,3}$, \\ Ladislav Dušek $^{1,4}$, and Ivan Holoubek ${ }^{1}$ \\ ${ }^{1}$ Research Centre for Toxic Compounds in the Environment, Faculty of Science, \\ Masaryk University, Kamenice 126/3, 62500 Brno, Czech Republic \\ ${ }^{2}$ Department of Experimental Biology, Faculty of Science, \\ Masaryk University, Kamenice 753/5, 62500 Brno, Czech Republic \\ ${ }^{3}$ Department of Chemistry, Faculty of Science, \\ Masaryk University, Kamenice 753/5, 62500 Brno, Czech Republic \\ ${ }^{4}$ Institute of Biostatistics and Analyses, \\ Masaryk University, Kamenice 126/3, 62500 Brno, Czech Republic \\ $\{\mathrm{klanova}, \mathrm{blaha}$, holoubek\}@recetox.muni.cz, \\ jiri@chemi.muni, klan@sci.muni.cz, dusek@iba.muni.cz
}

\begin{abstract}
Growing demand for data on the environmental impacts of persistent organic pollutants coming from legal and regional authorities as well as from private subjects, professionals and public resulted in initiation of the CETOCOEN project. This project is coordinated by the Research centre for toxic compounds in the environment of the Masaryk University in Brno and provides complex information supporting decision making and development of strategies related to protection of natural environment and human health.
\end{abstract}

Keywords: Persistent organic pollutants, POPs, ambient air, monitoring, Stockholm Convention, Global Monitoring Plan, CETOCOEN, MONET.

\section{Introduction}

Environmental problems including their social and economical impacts have to be set into the context of the overall development of society, as a good management of natural resources is one of the key aspects of sustainable development. Such management requires sufficient information on the key factors affecting environment, data on occurrence, fate, persistence and long-range transport of various chemicals, their accumulation in biota and food chains as well as on mechanisms of their toxicity, and related ecological and human health risks. Only such complex information can provide sufficient support for decision making and development of strategies related to protection of natural environment and human health. International cooperation in this field is crucial as the environmental pollution goes beyond the boundaries.

Growing demand for such information coming from legal and regional authorities as well as from private subjects, professionals and public resulted in initiation of the 
CETOCOEN (CEntre for TOxic COmpounds in the ENvironment) ${ }^{1}$ project of Operational Program Research and Development for Innovations ${ }^{2}$ supported from European Union (EU) Structural funds. The CETOCOEN project is coordinated by the Research centre for toxic compounds in the environment (RECETOX) ${ }^{3}$ of the Masaryk University in Brno.

\section{Background}

The centre addressing problems related to persistent organic pollutants (POPs) was established in 1996 and from the beginning it has been involved in a number of international networks and projects. In cooperation with the Czech Hydrometeorological Institute, the centre established the programme of integrated monitoring of POPs in all environmental matrices at the central European background station in Košetice in 1996.

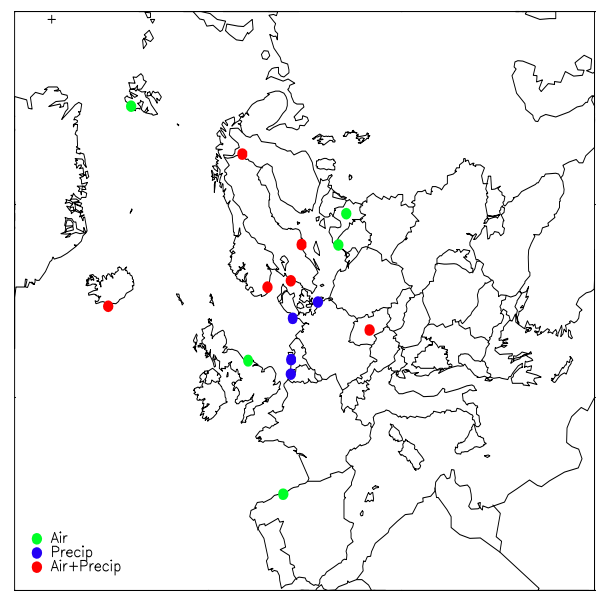

Fig. 1. Network of EMEP stations monitoring POPs

Unique data on long-term trends in environmental levels of polycyclic aromatic hydrocarbons (PAHs), polychlorinated biphenyls (PCBs) and organochlorine pesticides (OCPs) at European background are reported to the European Monitoring and Evaluation Programme (EMEP) ${ }^{4}$, a collaborative project addressing long-range transport of the air-born pollutants in Europe and supporting international Convention on Long-range Transboundary Air Pollution (CLRTAP) ${ }^{5}$ [1], [2], [3].

\footnotetext{
${ }^{1}$ http://www.cetocoen.cz/

${ }^{2}$ http://www.strukturalni-fondy.cz/getdoc/977e2e36-937e-4432-afe7-165afd87e676/ OP-Vyzkum-a-vyvoj-pro-inovace

${ }^{3} \mathrm{http} / / / \mathrm{www} \cdot$ recetox.muni.cz/index-en.php

${ }^{4} \mathrm{http}: / /$ www.emep.int/

${ }^{5} \mathrm{http}: / / \mathrm{www}$.unece.org/env/lrtap/
} 


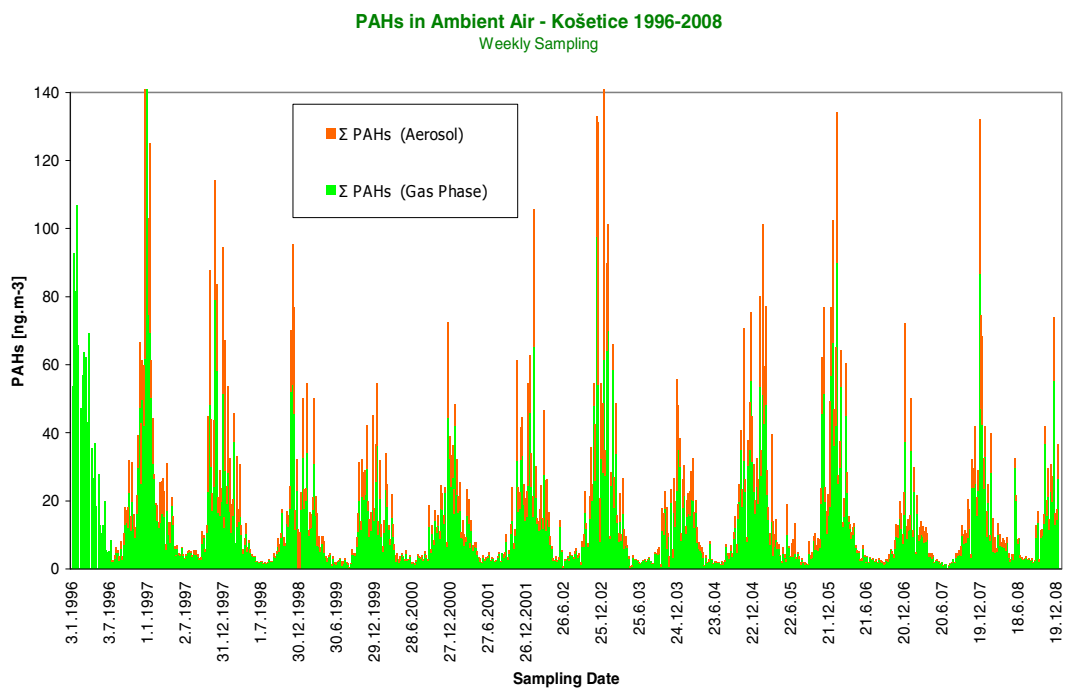

Fig. 2. Long-term trends of PAHs at the Košetice EMEP station

In the last decade, interactions among chemicals, environment and biological systems and their consequences at local, regional and global levels were the main focus of the centre. New approaches and experimental techniques were developed in photochemistry, toxicology, risk assessment, biostatistics, modelling and environmental informatics. Interdisciplinary links were established when addressing effects of the climate change on the contaminant cycling in the atmosphere [4 - 7].

In 2001-4, the centre coordinated the project funded by United Nations Industrial Development Organization (UNIDO) ${ }^{6}$ focused on implementation of the Stockholm Convention on Persistent Organic Pollutants (SC) ${ }^{7}$ in the Czech Republic. Consequently, a National centre for POPs ${ }^{8}$, was established as a part of RECETOX, an expert body focused on chemical and toxicological assessments of the chemicals being a subject of the international conventions ratified by the Czech Republic.

The centre serves the needs of government, ministries, regional authorities and industry, and provides new information on levels and fate of these chemicals, their toxicological properties and risks, and developing new methods of sampling, chemical analyses and effective toxicological testing.

In 2009, the Conference of the Parties of the Stockholm Convention of United Nations Environmental Programme (UNEP) ${ }^{9}$ officially endorsed RECETOX as a Regional Centre of the Stockholm Convention for capacity building and technology transfer in the region of Central and Eastern Europe ${ }^{10}$.

\footnotetext{
${ }^{6} \mathrm{http} / / /$ www.unido.org/

${ }^{7} \mathrm{http}: / / \mathrm{chm}$. pops.int/default.aspx

${ }^{8} \mathrm{http} / / /$ www.recetox.muni.cz/index-en.php?pg=national-pops-centre

${ }^{9} \mathrm{http} / / /$ hqweb.unep.org/

${ }^{10} \mathrm{http}: / / \mathrm{www}$. .recetox.muni.cz/index-en.php?pg=regional-pops-center
} 
In addition to above mentioned integrated POPs monitoring at the Košetice station, the centre has been developing the national network for monitoring of POPs in ambient air called MONET CZ (MOnitoring NETwork) ${ }^{11}$ since 2003 [8-10].

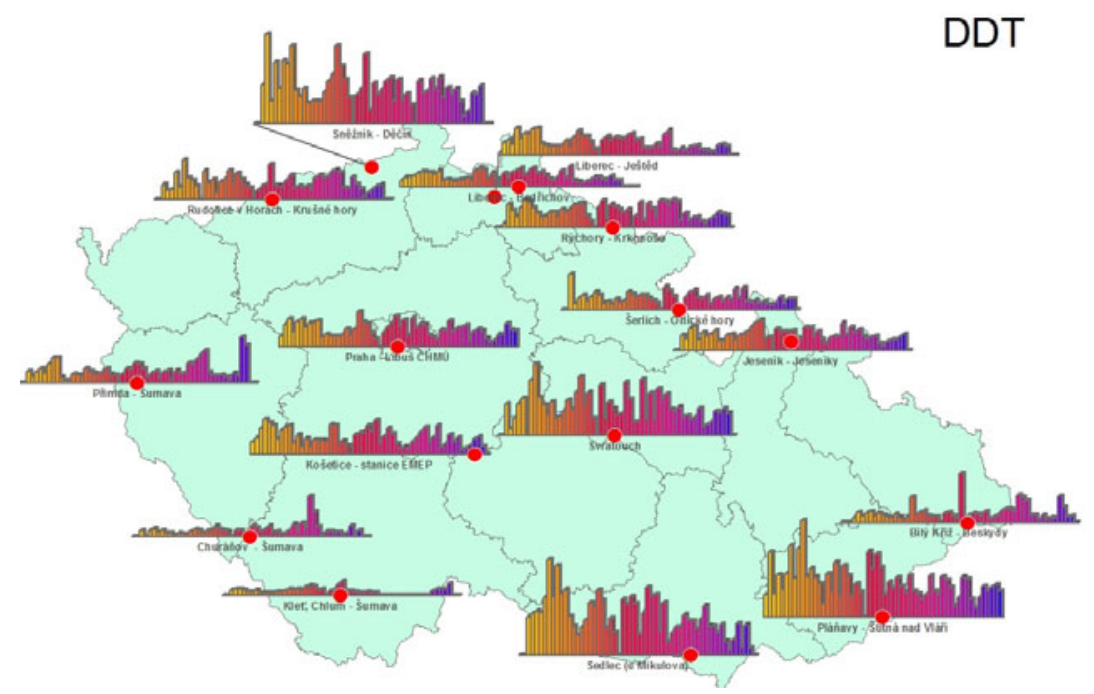

Fig. 3. Long term measurement of DDT and metabolites in ambient air at background stations of MONET network

Since 2004, MONET CZ has expanded to all Central and Eastern European (CEE) countries as MONET $\mathrm{CEE}^{12}$ and became a successful example of know-how and technology transfer in the region [11-15]. Passive air sampling technique was selected as an official tool for global monitoring of POPs, and RECETOX became a strategic partner for many world regions (CEE, Africa, Asia and Pacific) [16].

Currently, the centre operates the long-term air monitoring programme (MONET EU) at the EMEP stations in all European countries and executes the air monitoring programme in Africa (MONET AFRICA) supported from the EU . With a help of the Global Environmental Facility $(\mathrm{GEF})^{13}$ the centre also contributes to the development of analytical capacities in participating countries.

Vast number of samples collected in frames of such long-term monitoring programs introduced a problem of efficient data management. Robust environmental database was urgently needed as well as interactive tools permitting the user to validate, aggregate, analyze, and visualize data.

Due to the international and multilateral character of the MONET project, the centre faced a task to develop a web portal allowing professionals as well as general

\footnotetext{
${ }^{11} \mathrm{http} / / / \mathrm{www} . \mathrm{monet}-\mathrm{cz} . \mathrm{cz} /$

${ }^{12} \mathrm{http} / / /$ www.recetox.muni.cz/index-en.php?pg=regional-pops-center--scope-of-sc-rcactivities--monitoring-of-pops-in-the-cee-countries-and-other-regions

${ }^{13} \mathrm{http}: / / \mathrm{www}$.thegef.org/gef/home
} 
public to assess available environmental data providing them at the same time with the advanced analytical and modelling tools based on the Geographical information system (GIS).

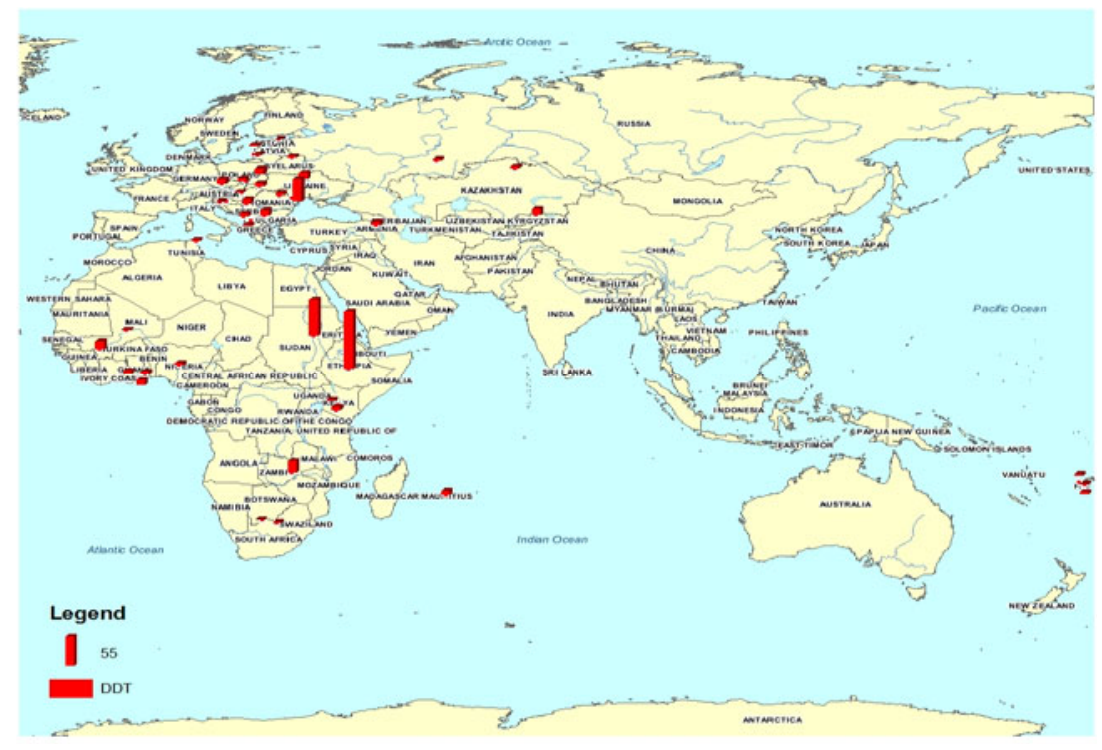

Fig. 4. Measurement of DDT and metabolites at the background stations of the MONET networks in Europe, Asia and Africa

\section{CETOCOEN Project and Its Goals}

In 2009, the research team of the centre prepared a successful project for the EU Structural funds, Operational programme Research and Development for Innovations, in the priority axis 2, Regional centres of applied research. The CETOCOEN project stemmed from the previous successful history of the centre and set new and ambitious goals. Following substantial enhancement of the laboratory capacities and human resources, the centre is expanding from the original fields of research to new directions including development of sampling and analytical methods for emerging environmental pollutants, laboratory and field studies of processes affecting the fate of chemical substances in the environment, development of biosensors and natural biocatalyzers, and assessment of toxic effects of chemical compounds and natural toxins on organisms.

Major contribution of the CETOCOEN project is improved understanding to the environmental fate of toxic compounds, their distribution among matrices, long range transport and bioaccumulation, degradation mechanisms of pollutants in various climatic regions with respect to increasing risks of their re-release due to the climate change, responsible assessment of toxic effects, and quantification of ecological and human health risks. The project will help to identify new classes of toxic chemicals suspected of persistence, bioaccumulation and long-range transport, which are major 
criteria for their listing in the global conventions on chemical safety. The centre is also involved in the Global monitoring plan (GMP) ${ }^{14}$. GMP is an activity developed under the Stockholm Convention with a purpose of providing a tool for effectiveness evaluation of the Stockholm Convention measures. First global assessment of current baseline levels of POPs in core matrices (ambient air and human milk) was completed in 2008. Majority of data on ambient air levels of POPs was collected using the passive air samplers (PAS) with a significant contribution of data from the MONET networks.

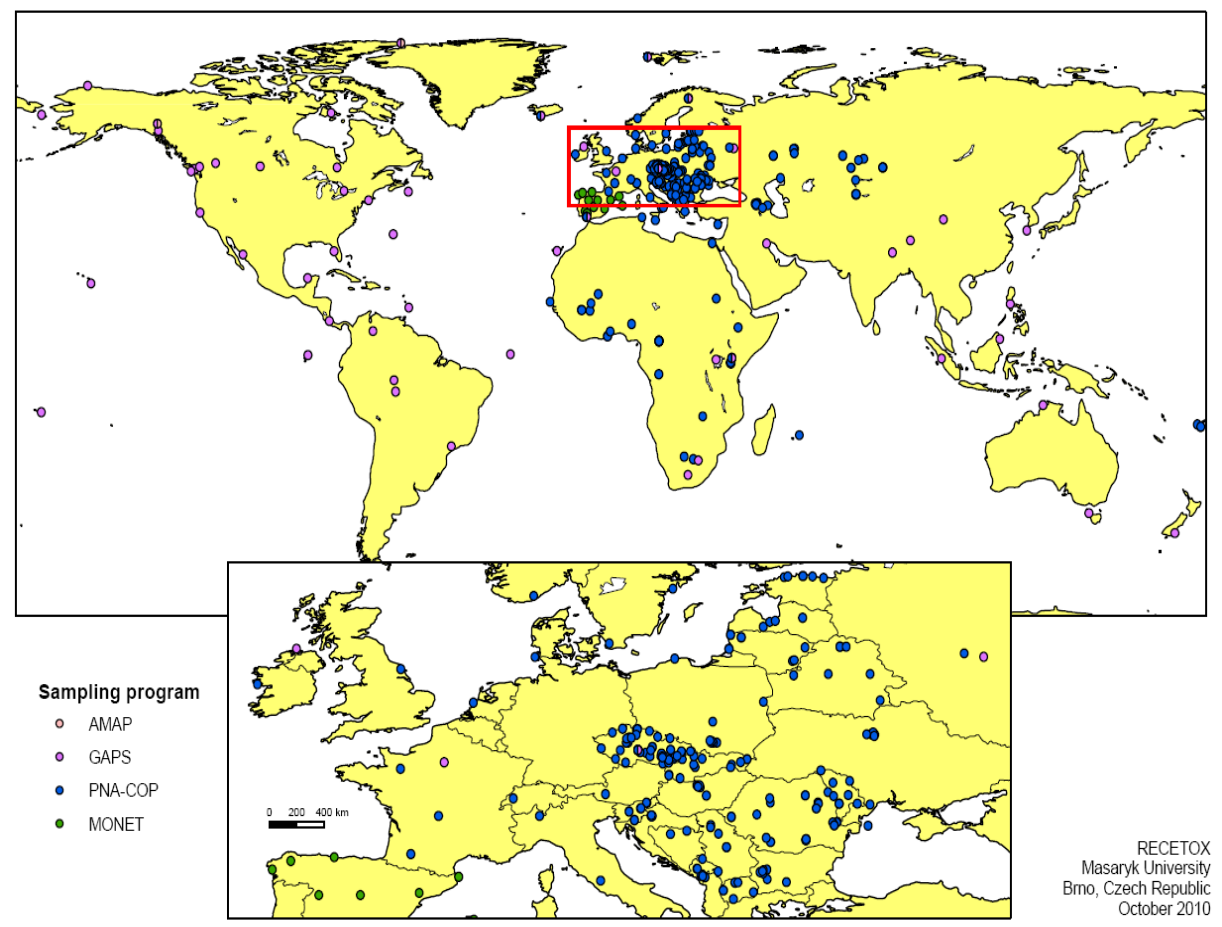

Fig. 5. Global distribution of the sampling sites with on-going air monitoring. MONET sampling sites are coloured blue.

In 2009, the Conference of the Parties of the SC decided that levels of POPs in core matrices will be assessed every six years assuming that such period will be sufficient for establishment of the temporal trends. As the Košetice station is the only site worldwide where active and passive samplers have been co-employed for full six years so far, results from this station have an important role in the intercalibration of both techniques, comparison of trends derived from both datasets, and development of future global monitoring programmes [17-19]. Long-term sustainability of such

\footnotetext{
${ }^{14}$ http://chm.pops.int/Programmes/Global\%20Monitoring\%20Plan/Overview/tabid/ 83/language/en-GB/Default.aspx
} 
monitoring programmes is of a great importance for a success of the Global monitoring plan.

To integrate available monitoring data reporting environmental levels of toxic chemicals with newly acquired knowledge on their behaviour and effects in a single database available to public and widely utilized requires a new type of software for simultaneous visualization and analyses of various types of data. Development of the mathematical models for quantification of mass transfers from primary and secondary sources, exposure of ecosystems and human, model simulations of distribution, transformation, and long range transport of POPs, as well as designing the software tools allowing the use of the whole database as expert system, is the most important task of the CETOCOEN project.

This unique environmental data system should be further linked to existing epidemiological databases in order to enhance our understanding to environmentally induced diseases and their triggering mechanisms. While epidemiological data are currently well organized, data from the environmental monitoring programmes are rather fractionated. This problem has been also recognized on the international level.

\section{Project Deliverables and Impacts}

Successful implementation of the CETOCOEN project, namely development of Global environmental assessment and information system (GENASIS) ${ }^{15}$ would provide professional platform and decision making tool supporting implementation of European legislation and international conventions on environment protection. At the same time, the GENASIS should function as a clearing house mechanism transferring know-how between experts, institutions, countries and regions.

The outcomes of the CETOCOEN project will serve to the government and national ministries by providing information services necessary to control compliance with international conventions, to update inventories, toxicological databases and risk profiles, to develop of monitoring networks and expert systems for interpretation of environmental data. They will support the regional state authorities coordinating studies of environmental quality, toxicological investigations and risk assessments. Impact assessments of industrial technologies, data on contamination of the working environment and assessment of related risks will be useful for industrial partners. Availability of such data may trigger transfer of environment-friendly technologies, development of new remediation methods and better education of experts.

The project reduces a problem of insufficient links between scientific and applied sector and, at the same time, it establishes the links between the applied research and higher education. It is closely related to the capacity building and technology transfer, supports development of the human resources and training of interdisciplinary educated experts for industrial innovations as well as public authorities.

Beside a scientific quality, the CETOCOEN project has also an important socialeconomical impact on the local and regional levels. It increases attractiveness of the region for the scientists and in so doing prevents a brain drain of young scientists, supports underdeveloped congress tourism, and enhances environmental education and public awareness in the region.

${ }^{15}$ http://www.genasis.cz/main-index/en/ 
Acknowledgments. This research received financial support from the CETOCOEN project of the European Structural Funds (CZ.1.05/2.1.00/01.0001), the Ministry of Education (MSM 0021622412) and the Ministry of Environment (SP1a3/29/07) of the Czech Republic.

\section{References}

1. Dvorska, A., Lammel, G., Klanova, J., Holoubek, I.: Košetice, Czech Republic - ten years of air pollution monitoring and four years of evaluating the origin of persistent organic pollutants. Environ. Pollut. 156(2), 403-408 (2008)

2. Holoubek, I., Klánová, J., Jarkovský, J., Kohoutek, J.: Trends in background levels of persistent organic pollutants at Kosetice observatory, Czech Republic. Part I. Ambient air and wet deposition 1988-2005. J. Environ. Monit. 9(6), 557-563 (2007)

3. Holoubek, I., Klánová, J., Jarkovský, J., Kubík, V., Helešic, J.: Trends in background levels of persistent organic pollutants at Kosetice observatory, Czech Republic. Part II. Aquatic and terrestric environments 1988-2005. J. Environ. Monit. 9(6), 564-571 (2007)

4. Lammel, G., Klánová, J., Kohoutek, J., Prokeš, R., Ries, L., Stohl, A.: Observation and origin of organochlorine pesticides, polychlorinated biphenyls and polycyclic aromatic hydrocarbons in the free troposphere over central Europe. Environ. Pollut. 157, 3264-3271 (2009)

5. Lammel, G., Klánová, J., Ilić, P., Kohoutek, J., Gasić, B., Kovacić, I., Lakić, N., Radić, R.: Polycyclic aromatic hydrocarbons on small spatial and temporal scales - I. Levels and variabilities. Atmos. Environ. 44, 5015-5021 (2010)

6. Lammel, G., Klánová, J., Ilić, P., Kohoutek, J., Gasić, B., Kovacić, I., Škrdlíková, L.: Polycyclic aromatic hydrocarbons on small spatial and temporal scales - II. Mass size distributions and gas-particle partitioning. Atmos. Environ. 44, 5022-5027 (2010)

7. Gasić, B., MacLeod, M., Klánová, J., Scheringer, M., Ilić, P., Lammel, G., Pajović, A., Breivik, K., Holoubek, I., Hungerbühler, K.: Quantification of sources of PCBs to the atmosphere in urban areas: A comparison of cities in North America, Western Europe and former Yugoslavia. Environ. Pollut. 158, 3230-3235 (2010)

8. Harner, T., Bartkow, M., Holoubek, I., Klanova, J., Sweetman, A.J., Wania, F., Jones, K.C.: *: Passive air sampling for persistent organic pollutants: introductory remarks to the Special Issue. Environ. Pollut. 144(2), 361-364 (2006)

9. Klánová, J., Kohoutek, J., Hamplová, L., Urbanová, P., Holoubek, I.: Passive air sampler as a tool for long-term air pollution monitoring: Part 1. Performance assessment for seasonal and spatial variations. Environmental Pollution 144(2), 393-405 (2006)

10. Čupr, P., Klánová, J., Bartoš, T., Flégrová, Z., Kohoutek, J., Holoubek, I.: Passive air sampler as a tool for long-term air pollution monitoring: Part 2. Air genotoxic potency screening assessment. Environ. Pollut. 144(2), 406-413 (2006)

11. Klánová, J., Kohoutek, J., Kostrhounová, R., Holoubek, I.: Are the residents of former Yugoslavia still exposed to elevated PCB levels due to the Balkan wars? Part 1: Air sampling in Croatia, Serbia, Bosnia \& Hercegovina. Environ. Int. 33(6), 719-726 (2007)

12. Klánová, J., Kohoutek, J., Čupr, P., Holoubek, I.: Are the residents of former Yugoslavia still exposed to elevated PCB levels due to the Balkan wars? Part 2: Passive air sampling network. Environ. Int. 33(6), 727-735 (2007)

13. Škarek, M., Čupr, P., Bartoš, T., Kohoutek, J., Klánová, J., Holoubek: A combined approach to the evaluation of organic air pollution - A case study of urban air in Sarajevo and Tuzla (Bosnia and Herzegovina). Sci. Tot. Environ. 384(1-3), 182-193 (2007) 
14. Růžičková, P., Klánová, J., Čupr, P., Lammel, G., Holoubek, I.: An assessment of air-soil exchange of polychlorinated biphenyls and organochlorine pesticides across Central and Southern Europe. Environ. Sci. Technol. 42(1), 179-185 (2008)

15. Bartoš, T., Čupr, P., Klánová, J., Holoubek, I.: Which compounds are most responsible for elevated human health risks in the Western Balkans? Environ. Int 35, 1066-1071 (2009)

16. Klánová, J., Čupr, P., Holoubek, I., Borůvková, J., Kareš, R., Tomšej, T., Ocelka, T.: Monitoring of persistent organic pollutants in Africa. Part 1: Passive air sampling across the continent in 2008. J. Environ. Monit. 11, 1952-1963 (2009)

17. Klánová, J., Čupr, P., Kohoutek, J., Harner, T.: Assessing meteorological parameters on the performance of PUF disks passive air samplers for POPs. Environ. Sci. Technol. 42(2), 550-555 (2008)

18. Chaemfa, C., Barber, J.L., Gocht, T., Harner, T., Holoubek, I., Klanova, J., Jones, K.C.: Field calibration of polyurethane foam (PUF) disk passive air samplers for PCBs and OC Pesticides. Environ. Pollut. 156(3), 1290-1297 (2008)

19. Chaemfa, C., Barber, J.L., Moeckel, C., Gocht, T., Harner, T., Holoubek, I., Klanova, J., Jones, K.C.: Field calibration of polyurethane foam (PUF) disk passive air samplers for PBDEs. J. Environ. Monit. 11, 1859-1865 (2009) 